\title{
Health Education Strategy for Improving the Attitude of Adults towards Covid-19 Precautions in Udenu
}

\section{Ruphina UN, Matthias UA and Michael OU*}

Department of Adult Education and Extra-Mural Studies, University of Nigeria, Nigeria

*Corresponding author: Michael O Ugwueze, Department of Adult Education and ExtraMural Studies, University of Nigeria, Nigeria, Email: michael.ugwueze.185109@unn.edu.ng

\section{Research Article}

Volume 3 Issue 6

Received Date: December 04, 2020

Published Date: December 24, 2020

DOI: $10.23880 /$ jqhe-16000196

\section{Abstract}

Introduction: Due to the rising cases of COVID-19 in Nigeria, the government has adopted some safety precautions to control the spread. However, the poor attitude of adults towards COVID-19 safety precautions has aided the spread of the virus.

Objective: This study investigated health education strategy for improving the attitude of adults towards COVID-19 safety precautions in Udenu.

Methods: The study is naturalistic observation study. The attitude of adults in Udenu towards COVID-19 towards COVID-19 safety precautions was observed before and after implementing a health education strategy so as to determine the effectiveness of the strategy in improving the attitude of adults towards COVID-19 safety precautions. 4 communities in Udenu were observed for the study.

Results: The findings revealed that there was a significant improvement in the attitude of the adult towards COVID-19 safety precautions after receiving health education. Hence, more community health workers should be trained by Nigerian Center for Disease Control (NCDC).

Keywords: Covid-19; Health Education; Adults; Attitude; Awareness

\section{Introduction}

The rate at which the novel COVID-19 is rising in Nigeria is a cause for worry and needs urgent addressing. As at July 24,2020 , out of the 256,038 samples tested, there are 38,948 confirmed positive cases of COVID-19 pandemic in Nigeria [1]. Even though these cases cut across all the 36 states in Nigeria, many citizens of the country do not believe that COVID-19 really exist in the country while another majority claim that rate of the virus spread is only being exaggerated. This disbelief on the existence or the severity of the COVID-19 in Nigeria has contributed significantly to its spread as people do not see the need to practice the COVID-19 safety precaution [2]. Hence, there is need to promptly improve the attitude of the citizens towards COVID-19 and its safety precautions.
COVID-19 is the name given to the novel corona virus by the World Health Organization (WHO). COVID-19 stands for Corona Virus Disease of 2019 which is an infectious disease caused by severe acute respiratory syndrome coronavirus 2 (SARS-CoV-2) [3]. COVID-19 primarily attacks the respiratory system and causes its victims to experience, mild, moderate or severe respiratory illness especially among older ones or people with underlying health problems [4]. Also, COVID-19 is primarily spread through respiratory droplets when an infected person coughs, sneezes or talks [5]. The spread of COVID-19 across the world is still on the rise with more than 15 million confirmed cases and almost 620 thousand deaths globally as at July 23,2020 [6]. The report also indicated that the worst hit countries include USA, UK, Italy and France among others; however, Nigeria and some other countries still have a rising rate of infections. 
Due to the rising cases of COVID-19 in Nigeria, the government has adopted some safety precautions to control the spread. The Federal Government of Nigeria has mandated the use of face masks or coverings in public, restricted social and religious gatherings and advised the citizens to regularly wash their hands with soap and running water and to frequently clean hard surfaces with soap and water or disinfectants. 1 These laws and guidelines were put in place to help slow down the spread of COVID-19 in Nigeria. However, it could be observed that many of the citizens are reluctant to obey these instructions except with force from security agencies. Some claim that as Christians, COVID-19 is not their portion; others claim that COVID-19 is a conspiracy in Nigeria; while some others who are daily wage earners choose to go all out for their daily meal even with the risk of contracting COVID-19 [7]. This affects the attitude of the adults towards COVID-19 safety precautions.

Adults are the major decision makes in the society. An adult is an individual who is physically and psychologically mature, and the individual is socially, economically, politically, culturally and environmentally responsible [8]. An adult is an individual who has achieved full physical development and is expected to have the right to participate as a responsible homemaker, worker and member of a society [9]. Hence, for the purpose of this study, adults refer to any member of the society who is physically and psychologically mature enough to make responsible decisions in the society; an adult should always be responsible for his or her attitude or behavior.

Attitude is the foundation and major determinant for a behavior. Attitude refers to the mental and emotional construct which defines the value which an individual attaches to something or someone [10]. Therefore, attitude could be seen as an individual's reaction toward a target object as a result of his or her beliefs or feelings about the object. This implies that the attitude of adults towards an activity determines their actions towards the activity. Hence, positive attitude would make adults in rural parts of Udenu to observe COVID-19 safety precautions such as regular hand washing, use of alcoholic hand sanitizer, use of face masks, social or physical distancing and self-isolation [1].

However, it could be observed that most adults in rural communities in Udenu do not observe these COVID-19 safety precautions. In some streets in the area, younger adults are seen playing football which is a game involving very close physical contact; both older and younger adult are also seen in ceremonies such as funeral and marriages without observing social distancing or putting on face masks; many business centers also function without making provisions for water and soap or hand sanitizer. These cases highlight the poor attitude of adults in rural communities of Udenu towards COVID-19 safety precautions; this could also lead to rapid increase in the spread of COVID-19 in the area. Hence, there is need to improve the attitude of the adults in Udenu towards COVID-19 safety precautions so as to help control the spread of the virus. Health education strategy could be effective for improving the attitude of the adults in Udenu towards COVID-19 safety precaution.

Health education is vital for creating awareness on the need for maintenance of COVID-19 safety precautions. Health education is the educational programme designed to equip youths and adults with adequate knowledge which will enable them take proper care of their health and the health of their community [11]. More so, health education seeks to raise awareness, improve knowledge and change the attitude of youths and adults so as to enable them engage only in healthy and safe behaviors [12]. Therefore, health education could help adult members of a society to acquire necessary awareness which would enable them to make good health decisions such as observing good hygiene and avoiding unnecessary contacts especially in this period of COVID-19 pandemic.

Health education strategy which could effectively improve the attitude of the adults in Udenu towards COVID-19 safety precaution is the use of community health workers for COVID-19 awareness creation. Community health workers in this context are members of a particular community who are neither professional doctors or nurses but have little training on health management; these community health workers might be offering health services on volunteer basis or on little remuneration [13]. The use of community health workers for COVID-19 awareness creation could have significant effect on the community members as they would be more eager to accept information from people they consider being part of them. More so, the community health workers could be in a better position to locate community members in the most interior parts of the community and they also have higher chance of being welcomed in people's homes. Hence, use of community health workers as a health education strategy could help to improve the attitude of the adults in Udenu towards COVID-19 safety precaution.

Udenu is one of the 17 Local Government Areas in Enugu State, Nigeria. It is located in the south eastern part of Nigeria and houses the famous University of Nigeria. 90\% of the communities in the local government area are rural communities possessing a lot of natural resources such as palm trees, cashew trees, streams and fertile land [14]. The report also indicates that majority of the community members are daily wage earners whose source of income is based on sales of goods and services. The largest markets in the local government area are the "Orba world market" and 
the "Obollo-afor market" which are often over crowded with buyers and sellers on a daily basis. It could be observed that even with the lockdown placed in the area; people still carry on with their business in these big markets with little or no adherence to COVID-19 safety precautions. Table 1 below revealed the initial observed attitude of people in Udenu Local government area to COVID-19 safety precautions such as wearing of face mask, observing physical distancing, and regular sanitizing of hand using soap, water and alcohol based sanitizer.

\begin{tabular}{|c|c|c|c|c|c|}
\hline \multicolumn{2}{|c|}{ People wearing face mask to market } & \multicolumn{2}{|c|}{ People wearing face mask to church } & \multicolumn{2}{|c|}{$\begin{array}{l}\text { People wearing face mask while } \\
\text { riding a motorcycle }\end{array}$} \\
\hline Community & Percentage (\%) & Community & Percentage (\%) & Community & Percentage (\%) \\
\hline Ezimo & 31 & Ezimo & 54 & Ezimo & 11 \\
\hline Igugu & 29 & Igugu & 46 & Igugu & 20 \\
\hline Umundu & 27 & Umundu & 47 & Umundu & 15 \\
\hline Imilike & 33 & Imilike & 56 & Imilike & 17 \\
\hline \multicolumn{2}{|c|}{ Houses with hand sanitizing facilities } & \multicolumn{2}{|c|}{$\begin{array}{l}\text { Churches with hand sanitizing } \\
\text { facilities }\end{array}$} & \multicolumn{2}{|c|}{$\begin{array}{l}\text { Business centers with hand } \\
\text { sanitizing facilities }\end{array}$} \\
\hline Ezimo & 10 & Ezimo & 56 & Ezimo & 41 \\
\hline Igugu & 7 & Igugu & 59 & Igugu & 39 \\
\hline Umundu & 18 & Umundu & 53 & Umundu & 39 \\
\hline Imilike & 14 & Imilike & 48 & Imilike & 47 \\
\hline \multicolumn{2}{|c|}{$\begin{array}{l}\text { People observing physical distancing } \\
\text { in churches }\end{array}$} & \multicolumn{2}{|c|}{$\begin{array}{l}\text { People observing physical distancing } \\
\text { in business centers }\end{array}$} & \multicolumn{2}{|c|}{$\begin{array}{l}\text { People observing physical distancing } \\
\text { in ceremonies }\end{array}$} \\
\hline Ezimo & 25 & Ezimo & 20 & Ezimo & 12 \\
\hline Igugu & 19 & Igugu & 16 & Igugu & 9 \\
\hline Umundu & 22 & Umundu & 20 & Umundu & 10 \\
\hline Imilike & 18 & Imilike & 13 & Imilike & 5 \\
\hline
\end{tabular}

Table 1: Initial attitude of people in Udenu Local government area to COVID-19 safety precautions.

The streets in Udenu Local government area are still filled up with people without face masks and who exchange hugs and handshakes and talk very close to each other; more so, large crowd still gather for ceremonies; people do not wash or sanitize their hands regularly. Furthermore, some of the adults believe that the cure to COVID-19 is prayer; therefore, they continue going to church even without observing social distancing. The government of the area has inaugurated various task forces for enforcing COVID-19 safety precautions; however, this has not been very effective as the people have ways of avoiding the taskforce agents. This is mostly as a result of the fact that the people see COVID-19 as a conspiracy used by the government to loot money while other feel that the virus is not strong enough to survive in the region. Therefore, this study seeks to assess the extent the use of community health workers as a health education strategy could improve the attitude of adults in Udenu towards COVID-19 safety precautions such as wearing of face mask, observing physical distancing, regular sanitizing of hand using soap, water and alcohol based sanitizer.

\section{Methods}

\section{Study Design and Setting}

The study is naturalistic observation study. Naturalistic observation research was used as the researchers were interested in studying the attitude of the adults in Udenu towards COVID-19 safety precautions before and after taking COVID-19 awareness education to them through community health workers. This will enable the researchers to determine the extent to which the use of community health workers improved their attitude towards COVID-19 safety precautions. Naturalistic observation method is a nonexperimental research method (often qualitative) which allows the study of organisms in their natural setting with or without the knowledge of the organisms [15].

This naturalistic observation study was carried out in 4 communities in Udenu Local Government Area of Enugu State, Nigeria. The communities include Ezimo, Igugu, Umundu 
and Imilike. These communities were chosen because the researchers observed that members of the communities do not have the desired attitude towards COVID-19 safety precautions. It was observed that the attitude of these 4 communities towards wearing of face masks, washing and sanitizing of hand and observing physical distancing are collectively poor.

Furthermore, Igugu and Imilike were randomly selected as the control group and they received COVID-19 awareness programme by trained community health workers. Upon the completion of the COVID-19 awareness programme by trained community health worker, the extent of change in the attitude of the community members in Igugu and Imilike (the control group) towards COVID-19 safety precautions over a period of time was compared with those in Ezimo and Umundu over the same period of time. This would enable the researchers to determine the extent to which the use of community health workers improved the attitude of the adults in the selected communities towards COVID-19 safety precautions. The study was carried out in these communities from March 5, 2020 to June 30, 2020.

Purposive sampling technique was used to select fifty (50) household each from Igugu and Imilike communities making up a hundred (100) household who received COVID-19 awareness programme by trained community health worker. The choice of these households was as a result of them having a population of 7 family members and above.
The COVID-19 awareness programme lasted for 1 month and was carried out Monday to Friday between the hours of $5 \mathrm{pm}$ to $7 \mathrm{pm}$ in the evening when majority of the house hold were expected to be in the house. Each household received the awareness programme in their various houses. Hence, based on data recorded by the trained community health worker, 774 individuals received the COVID-19 awareness programme.

\section{Instruments for Data Collection}

The researchers made use of note books, camera and audio recordings to record their observations. These tools were used so as to ensure that the data collection and analytical process is valid. The note books, camera and audio recording will help all the researchers and their assistants to collectively analyze the data collected. The fifteen (15) observers placed themselves in strategic position of the study communities from 7:30am to $6 \mathrm{pm}$ and took note of peoples' behavior without their knowledge.

\section{Data Analysis}

Data was analyzed qualitatively. The observation recordings were graded in frequency and percentage so as to answer the following question: What is the attitude of people in Udenu communities towards

- Wearing of face masks

- Providing hand sanitizing facilities and

- Observing Physical distancing

\section{Results and Discussion}

\begin{tabular}{|c|c|c|c|c|c|}
\hline \multicolumn{2}{|c|}{$\begin{array}{c}\text { People wearing face mask to } \\
\text { market }\end{array}$} & \multicolumn{2}{c|}{$\begin{array}{c}\text { People wearing face mask to } \\
\text { church }\end{array}$} & \multicolumn{2}{c|}{$\begin{array}{c}\text { People wearing face mask while riding a } \\
\text { motorcycle }\end{array}$} \\
Community & Percentage (\%) & Community & Percentage (\%) & Community & Percentage (\%) \\
\hline Ezimo & 32 & Ezimo & 54 & Ezimo & 10 \\
\hline Igugu & 69 & Igugu & 94 & Igugu & 69 \\
\hline Umundu & 30 & Umundu & 49 & Umundu & 15 \\
\hline Imilike & 74 & Imilike & 92 & Imilike & 77 \\
\hline
\end{tabular}

Table 2: Percentage rating on the attitude of people towards wearing of face masks in Udenu after the period of COVID-19 awareness programme by trained community health worker.

Table 2 above revealed the percentage rating on the attitude of people towards wearing of face masks in Udenu after the period of COVID-19 awareness programme by trained community health worker. The table shows that after the period of COVID-19 awareness programme by trained community health worker, the percentage of people wearing face mask to market in Ezimo is (32\%), Igugu (69\%), Umundu (30\%) and Imilike (74\%); while the percentage of people wearing face mask to Church in Ezimo is (54\%), Igugu (94\%),
Umundu (49\%) and Imilike (92\%). Finally, the percentage of people wearing face mask while riding a motorcycle in Ezimo is (10\%), Igugu (69\%), Umundu (15\%) and Imilike $(77 \%)$. This indicates that there is a significant change in the attitude of people towards wearing of face masks in Udenu after the period of COVID-19 awareness programme by trained community health worker when compared with initial attitude of people in Udenu Local government area to COVID-19 safety precautions in table 1 . 
While comparing Table 1 and table 2 , it is obvious that these significant changes could be noticed in just the two communities (Igugu and Imilike) who received COVID-19 awareness programme by trained community health worker. After receiving COVID-19 awareness programme by trained community health worker, the people wearing face mask to market improved significantly from $29 \%$ to $69 \%$ in Igugu; also from $33 \%$ to $74 \%$ in Imilike. While the people wearing face mask to church also improved significantly from $46 \%$ to $94 \%$ in Igugu; also from $56 \%$ to $92 \%$ in Imilike. More so, the people wearing face mask while riding a motorcycle significantly improved from $20 \%$ to $69 \%$ in Igugu; also, from $17 \%$ to $77 \%$ in Imilike. However, evidence from table 1 and 2 also revealed that there was no significant improvement in the attitude of people towards wearing of face masks in other two communities (Ezimo and Umundu) who did not received COVID-19 awareness programme by trained community health worker.

\begin{tabular}{|c|c|c|c|c|c|}
\hline \multicolumn{2}{|c|}{$\begin{array}{c}\text { Houses with hand sanitizing } \\
\text { facilities }\end{array}$} & \multicolumn{2}{c|}{$\begin{array}{c}\text { Churches with hand sanitizing } \\
\text { facilities }\end{array}$} & \multicolumn{2}{c|}{$\begin{array}{c}\text { Business centers with hand sanitizing } \\
\text { facilities }\end{array}$} \\
\hline Community & Percentage (\%) & Community & Percentage (\%) & Community & Percentage (\%) \\
\hline Ezimo & 10 & Ezimo & 58 & Ezimo & 40 \\
\hline Igugu & 51 & Igugu & 96 & Igugu & 79 \\
\hline Umundu & 14 & Umundu & 53 & Umundu & 35 \\
\hline Imilike & 56 & Imilike & 96 & Imilike & 87 \\
\hline
\end{tabular}

Table 3: Percentage rating on the attitude of people towards the provision of hand sanitizing facilities in Udenu after the period of COVID-19 awareness programme by trained community health worker.

Table 3 above revealed the percentage rating on the attitude of people towards the provision of hand sanitizing facilities in Udenu after the period of COVID-19 awareness programme by trained community health worker. The table shows that after the period of COVID-19 awareness programme by trained community health worker, the percentage of houses with hand sanitizing facilities in Ezimo is (10\%), Igugu (51\%), Umundu (14\%) and Imilike (56\%). While the percentage of churches with hand sanitizing facilities in Ezimo is (58\%), Igugu (96\%), Umundu (53\%) and Imilike (96\%). More so, the percentage of business centers with hand sanitizing facilities in Ezimo is (40\%), Igugu (79\%), Umundu (35) and Imilike (87\%). This indicates that there is a significant change in the attitude of people towards the provision of hand sanitizing facilities in Udenu after the period of COVID-19 awareness programme by trained community health worker when compared with initial attitude of people in Udenu Local government area to COVID-19 safety precautions in table 1.
While also comparing Table 1 and table 3 , it is obvious that these significant changes could be noticed in just the two communities (Igugu and Imilike) who received COVID-19 awareness programme by trained community health worker. After receiving COVID-19 awareness programme by trained community health worker, the percentage of houses with hand sanitizing facilities improved significantly from $7 \%$ to $51 \%$ in Igugu; also, from $14 \%$ to $56 \%$ in Imilike. While the percentage of churches with hand sanitizing facilities improved significantly from $59 \%$ to $96 \%$ in Igugu; also, from $48 \%$ to $96 \%$ in Imilike. Furthermore, the percentage of business centers with hand sanitizing facilities improved significantly from $39 \%$ to $79 \%$ in Igugu; also, from $47 \%$ to $87 \%$ in imilike. However, evidence from table 1 and 3 also revealed that there was no significant improvement in the attitude of people towards provision of hand sanitizing facilities in the other two communities (Ezimo and Umundu) who did not received COVID-19 awareness programme by trained community health worker.

\begin{tabular}{|c|c|c|c|c|c|}
\hline \multicolumn{2}{|c|}{$\begin{array}{c}\text { People observing physical } \\
\text { distancing in churches }\end{array}$} & $\begin{array}{c}\text { People observing physical distancing } \\
\text { in business centers }\end{array}$ & $\begin{array}{c}\text { People observing physical distancing } \\
\text { in ceremonies }\end{array}$ \\
\hline Community & Percentage (\%) & Community & Percentage (\%) & Community & Percentage (\%) \\
\hline Ezimo & 26 & Ezimo & 21 & Ezimo & 12 \\
\hline Igugu & 61 & Igugu & 53 & Igugu & 49 \\
\hline Umundu & 24 & Umundu & 20 & Umundu & 10 \\
\hline Imilike & 67 & Imilike & 57 & Imilike & 52 \\
\hline
\end{tabular}

Table 4: Percentage rating on the attitude of people towards the observation of physical distancing in Udenu after the period of COVID-19 awareness programme by trained community health worker. 
Table 4 above revealed the percentage rating on the attitude of people towards the observation of physical distancing in Udenu after the period of COVID-19 awareness programme by trained community health worker. The table shows that after the period of COVID-19 awareness programme by trained community health worker, the percentage of people observing physical distancing in churches in Ezimo is (26\%), Igugu (61\%), Umundu (24\%) and Imilike (67\%). While the percentage of people observing physical distancing in business centers in Ezimo is (21\%), Igugu (53\%), Umundu (20\%) and Imilike (57\%). More so, the percentage of people observing physical distancing in ceremonies in Ezimo is (12\%), Igugu (49\%), Umundu (10\%) and Imilike (52\%). This indicates that there is a significant change in the attitude of people towards the observation of physical distancing in Udenu after the period of COVID-19 awareness programme by trained community health worker when compared with initial attitude of people in Udenu Local government area to COVID-19 safety precautions in table 1.

However, comparing tables 1 and 4 revealed that these significant changes could be noticed in just the two communities (Igugu and Imilike) who received COVID-19 awareness programme by trained community health worker. After receiving COVID-19 awareness programme by trained community health worker, the percentage of people observing physical distancing in churches significantly improved from $19 \%$ to $61 \%$ in Igugu; also, from $18 \%$ to $67 \%$ in Imilike. While the percentage of people observing physical distancing in business centers significantly improved from 16\% to 53\% in Igugu; also, from $13 \%$ to $57 \%$ in Imilike. Furthermore, the percentage of people observing physical distancing in ceremonies significantly improved from $9 \%$ to $49 \%$ in Igugu; also, from $5 \%$ to $52 \%$ in Imilike. However, evidence from table 1 and 4 also revealed that there was no significant improvement in the attitude of people towards observation of physical distancing in the other two communities (Ezimo and Umundu) who did not received COVID-19 awareness programme by trained community health worker.

Therefore, after comparing the observation data in tables 1-4, it is clear that COVID-19 awareness programme by trained community health worker as a health education strategy is very effective in improving the attitude of adults towards COVID-19 safety precautions. This is so because, the two communities who received COVID-19 awareness programme by trained community health worker recorded significant improvement in their attitude towards COVID-19 safety precautions such as wearing of face mask, observing physical distancing, and regular sanitizing of hand using soap, water and alcohol based sanitizer. While the two other communities who did not receive COVID-19 awareness programme by trained community health worker continued to display poor attitude towards COVID-19 safety precautions such as wearing of face mask, observing physical distancing, and regular sanitizing of hand using soap, water and alcohol based sanitizer. This is in line with the earlier finding which stated that improved COVID-19 knowledge and awareness would most likely lead to a more positive attitude towards COVID-19 safety precautions [16].

This earlier finding also made it clear that health education strategies could be used to improve peoples' COVID-19 knowledge and awareness. This will thus, enable them to develop a more positive attitude towards COVID-19 safety precautions. Hence, this explains why the two communities which received COVID-19 awareness programme by trained community health worker recorded significant improvement in their attitude towards COVID-19 safety precautions while the other communities continued to display poor attitude towards COVID-19 safety precautions. The use of community health workers improve the link between the members of the community and health care providers [17]. This is so because the community health workers are also a closer part of the community.

Hence, itis also understandable why the use of community health workers for the COVID-19 awareness programme yielded a positive result. Due to the fact that the trained community health workers were part of the communities, spoke their language and understood their culture, it was easier for them to reach the hearts of the community members. The community members welcomed them fully and were willing to practice what these trained community health workers taught them. Therefore, COVID-19 awareness programme by trained community health worker as a health education strategy is very effective in improving the attitude of adults towards COVID-19 safety precautions.

\section{Conclusion}

The increase in the rate of COVID-19 in Nigerian communities is related to the poor knowledge and attitude of the community members towards COVID-19 pandemic. Majority of the citizens believe that COVID-19 in Nigeria in not as serious as the government make it seem. Hence, there is a need to improve the COVID-19 knowledge and attitude of the members of the community. This could be done effectively through health education strategy such as the use of trained community health workers for COVID-19 awareness programme. The community health workers have the potential to reach a larger number of community members and also have the ability to make the community members adopt the COVID-19 safety precautions proposed to them. Thus, this paper is recommending that the Nigerian Center for Disease Control (NCDC) should collaborate with primary health care development agencies in various Nigerian states to train more community health workers 
to carry out COVID-19 awareness programmme in various communities. This will help to increase the COVID-19 knowledge and awareness of the people and hence help them develop a more positive attitude towards COVID-19 safety precautions.

\section{$>$ Funding}

The authors did not receive support from any organization for the submitted work.

\section{$>$ Competing Interests}

The authors have no conflict of interest to declare that are relevant to the content of this article.

\section{$>$ Authors' Contribution}

RUN was the leading author. She collaborated with MUA in the study conception and design. Material preparation, data collection and analysis were prepared by RUN and MUO. The first draft of the manuscript was prepared by RUN and the authors commented on the previous version of the manuscript. All authors read and approved the final manuscript.

$>$ Conflict of Interest

The authors declare that there are no conflicting interests.

\section{References}

1. Furtak M, Ksiazek P, Warchol S (2011) Develpoment of health care market-forecasts for the future. Zdr Publ 121(1): 76-80.

2. Hoechner H (2020) In northern Nigeria, distrust jeopardizes the response to coronavirus. The Conversation.

3. Ibeh AE (2008) Theory and Practice of adult education in Nigeria. University of Port Harcourt Press.

4. Johnson B (2010) Roles of health Education in Primary Care Services. Journal of Environmental and Biological science 12 (4): 48-59.

5. Kerry S, Beckham SW, Margaret G, George P, Krishna DR, et al. (2018) What do we know about communitybased health worker programs? A systematic review of existing reviews on community health workers. Human Resources for Health 16(39): 1-17.

6. Neil JS (2010) Encyclopedia of research design. Sage publications.

7. Nigeria Centre for Disease Control (2020) Advisory on the use of masks. Federal Ministry of Health, Nigeria.

8. Nigeria Centre for Disease Control (NCDC) (2020) COVID-19 Nigeria.

9. Nzeneri IS (2010) Adults in battle: any hope of victory? Inaugural lecture series, University of Port-Harcourt.

10. Orji O (2020) COVID-19: Why Nigeria may be worse than Italy. Punch Newspapers.

11. Perloff RM (2016) The dynamics of persuasion: Communication and attitudes in the $21^{\text {st }}$ century, $3^{\text {rd }}$ (Edn.), Routledge Taylor \& Francis.

12. Torres S, Labonte R, Spitzer D, Andrew C, Amaratunga $C$ (2014) Improving health equity: The promising role of community health workers in Canada. Healthc policy 10(1): 73-85.

13. Udenu Local Government Agency (2019) Udenu Local Government medium term development plan (Enugu State Local Government System).

14. World Health Organization (2020) Advice on the use of masks in the Context of COVID-19.

15. World Health Organization (2020) WHO DirectorGeneral's remarks at the media briefing on 2019-nCoV.

16. World Health Organization (2020) WHO DirectorGeneral's opening remarks at the media briefing on Covid-19.

17. Bao LZ, Wei L, Li HM, Qian QZ, Liu X Ge, et al. (2020) Knowledge, attitudes, and practices towards COVID-19 among Chinese residents during the rapid rise period of the COVID-19 outbreak: a quick online cross-sectional survey. International J of Biol Sci 16 (10): 1745-1752. 